\title{
Heroes of agricultural innovation
}

\author{
COR VAN DER WEELE AND JOZEF KEULARTZ ${ }^{1}$
}

New technology has a prominent place in the theory and practice of innovation, but the association between high tech and innovation is not inevitable. In this paper, we discuss six metaphorical heroes of agricultural innovation, starting with the dominant hero of frontier science and technology. At first sight, our six heroes can be divided in those who are pro- and those who are anti-technology. Yet in the end technology, and more specifically GM technology, does not emerge as the main issue. Empowering the poor, finding solutions for urgent climate problems, and enhancing the quality of our daily relations to food and the environment - these are the issues the heroes are fighting for. Relations between innovation and (frontier) technology are better seen as a matter of pragmatic consideration, we will argue.

\section{Introduction}

New technology has a prominent place in the theory and practice of innovation, even to the extent that it may seem self-evident that innovation is associated with developments on the frontiers of science and technology. But the association between innovation and new technology is not inevitable. With regard to agriculture, for example, the International Assessment of Agricultural Knowledge, Science and Technology for Development (IAASTD) put the emphasis elsewhere. ${ }^{2}$ In assessing how to harness agricultural knowledge, science and technology to reduce hunger and poverty, it put poor farmers at the centre. Opportunities should be created for them, IAASTD said, and to that end traditional and community-based knowledge should be integrated. These recommendations did not emerge without tension and disagreement. Representatives of Monsanto and Syngenta left the meetings prematurely, complaining that the assessment was "hijacked" by opponents of GM technology. In an analysis in Science, one of the co-chairs of IAASTD looked back on the process and said that these tensions reflected very different "worldviews" of agriculture; one in which agriculture has a multifunctional role that includes landscape and cultural heritage, versus one that sees agriculture as an industrial process of food production. ${ }^{3}$

In this paper, we will not approach agricultural innovation from a single overarching view. Instead, we distinguish concrete innovative strategies through a focus on metaphors: we present an inventory of heterogeneous innovative quests, and characterize their protagonists as heroes. "Hero" is a concept with different meanings. The mythical heroes, like Achilles or Hercules, are warriors of great strength and bravery. But "hero" also refers to courageous people in a broader sense or to people of great and inspiring deeds. Finally, in literature a hero is "just" the central person in a story, who may just as well be an "anti-hero" when it comes to courage. The heroes in this paper are real heroes in the sense that they confront dangers, at least to some extent, as they all set out to do new things in the real world. In calling them heroes, we want to highlight that courageous effort takes many forms. Some of them

Genomics, Society and Policy, Vol.5, No.3 (2009) ISSN: 1746-5354

(C) ESRC Genomics Network. 
(especially the first one) are more easily visible than others (especially the last one). One aim of the paper is to draw attention to some of the less heralded heroes. ${ }^{4}$

Our six heroes of agricultural innovation represent no attempt at comprehensiveness, they simply can be found when we look around, but they do represent a range. ${ }^{5}$ The first three are associated with high tech innovation, the next three with low tech. We are not arguing that one of them is the 'best'; we cherish the multitude and we think that pluralism is important because different views enrich each other. For that reason, neglected heroes deserve more attention, and dominant ones could do with less. Such a shift has similarities with a change that has been observed from the perspective of innovation studies, a change from innovation originating (only) in R\&D laboratories, to a new model in which innovation (also) originates in many other places. The latter is more associated with re-use and recombination of knowledge and is sometimes referred to as "innovation without research". ${ }^{6}$ We will not elaborate these similarities, as we focus on metaphors and their underlying patterns.

Wondering about underlying connections and distinctions, we will play with the idea that family metaphors might shed light on the difference between high tech and low tech heroes. George Lakoff describes American political thought through a dualism of family metaphors. ${ }^{7}$ In the conservative worldview, a strict father is the centre of the family, while in the liberal view, the family is a more egalitarian structure, and parents are first of all empathetic. What about these metaphors in an innovation context: can we distinguish between a high tech family and a low tech innovation family?

But however central technology may appear to be in the differences between our heroes, we will argue that technology is not their central concern; they fight against poverty, for the power to solve problems and shape the future, and for the quality of our relations to nature.

\section{Pioneering frontier men in the age of DNA}

In capturing the spirit and identity of the USA, no metaphor probably surpasses the mythical power of the frontier, articulated by Turner in 1893 . The great westward expansion signified a journey into the unknown, a transformation of the wilderness, the idea of fresh beginnings and shaking off old European habits. The frontier produced democracy American-style, rooted in individualism. And it is to the frontier, Turner said, that the American intellect owes it striking characteristics:

That coarseness and strength combined with acuteness and inquisitiveness; that practical, inventive turn of mind, quick to find expedients; that masterful grasp of material things, lacking in the artistic but powerful to effect great ends, that restless, nervous energy, that dominant individualism, working for good and for evil, and withal that buoyance and exuberance that comes with freedom.

The "frontier hypothesis", or myth, or metaphor, is archetypically heroic, and it continues to inspire. ${ }^{9}$ It inspires scientific and entrepreneurial endeavors as well as 
their combination. In a paper on metaphors of morality in the Human Genome Project, Alice Dreger noted its frequent use. ${ }^{10}$ First of all, the Human Genome Project is "simply part of the great American tradition of bold exploration and settlement." Further and more specifically, the effort to chart genetic mysteries is regularly compared to the exploratory journey of Lewis and Clark and the opening up of the American West.

One frontier hero in present day biotechnology is Craig Venter, who has launched bold projects of discovery on the human genome and more recently on synthetic biology. In his Dimbleby lecture ${ }^{11}$ he discusses the prospects of synthetic biology with characteristic ambition. What we need, he said, is new technology that is disruptive in the sense that it overturns existing technologies and the status quo. The goal is no more and no less than to solve the most urgent problems of the world. Science and technology, and genetic technologies in particular, according to Venter, will provide the key to our future survival. The title of the lecture, 'A DNA-driven world', reflects this belief. The quest is not only to understand and manipulate life on the genetic level, but to design it bottom up.

Venter's way forward is to be bold and entrepreneurial (Venter is patenting his discoveries), ${ }^{12}$ and he thinks that a reliance on new technology is the only way forward if we want to save the world. It is wrong to be sceptical, prudent, hesitant: he condemns scepticism as being "pedantic". ${ }^{13}$

A frontier hero discovers the unknown. His actions may be rough, disruptive, even aggressive, but this boldness is needed to tame the dangerous unknown out there. Civilizing activities and rounding off the rough edges can wait till later. Frontier morality and frontier heroism are vital, easy to recognize, almost archetypically heroic. Its orientation towards action is also reminiscent of Keynes' famous remark about the inherent optimism of our "animal spirits": "Most, probably, of our decisions to do something positive, the full consequences of which will be drawn out over many days to come, can only be taken as the result of animal spirits - a spontaneous urge to action rather than inaction, and not as the outcome of a weighted average of quantitative benefits multiplied by quantitative probabilities." 14

\section{Civilizing activities within the household and from outside}

At the historical American frontier, civilizing activities and rounding off rough edges were predominantly women's work, according to the analysis of Julie Jeffrey in her book Frontier Women. ${ }^{15}$ In contrast to what is sometimes thought, she writes, the social roles of men and women, that had become separate when the house was no longer the place where money was earned, remained separate on the frontier. The world of men was and remained outside, public, competitive and dangerous. Women's sphere was the home, where they provided not only safety and tranquillity, but were also responsible for maintaining moral and cultural values. 
Here is the second hero: she is the companion and housekeeper of the first, depending on him in her activities. She is a civilizing heroine, defending values and protecting the vulnerable family against the bold harshness of the frontier world.

In the context of genomics, the role of the ELSI program is comparable to the role of women at the frontier. ELSI takes the developments of genomic science as a starting point, wonders about the ethical, legal and social implications, and guards morality. ELSI civilizes genomics. Bioethics in general can be argued to have this housekeeping role in relation to the life sciences, as it often defines itself in relation to science. For example, the Dutch Society of Bioethics explains on its website that bioethics is the branch of ethics that focuses on questions arising from developments in the life sciences.

The role of ELSI, like that of women at the frontier, is derivative and secondary. This applies even to her moral role, since the primary heroic moral activity is the expansive frontier bravery which lays the foundations of a new world. ELSI will take care of civilizing the technology, smoothing the rough edges. She is far more inconspicuous than her husband, the genomics researchers. In this model of the relation between science and society, science takes the lead. ${ }^{16}$

While ELSI operates within the household, others have taken up similar tasks from more independent positions. They are inspectors rather than housekeepers. Greenpeace is such a critical inspector of biotechnology, as is the Canadian ETC group. Let us look in a little more detail at the latter. The ETC (formerly RAFI) ${ }^{17}$ group is an international organization that places central value on sustainability and human rights, and focuses on the impact of agricultural biotechnology on the poorest and most vulnerable. As the group explains on its homepage, it wants to ensure that "the powerful recognize that the world's marginalized populations and ecologies are not a petri dish for technological advancement."

Patents on living material have become a central target of ETC. In 2008, for example, the group focused on patents in the field of stress-tolerant crops. Climate change comes with the threat that ever more crops will have to grow in environments that are plagued by drought, salinity, heat, cold, nutrient deficiency, UV irradiation, and so on. In response to these threats, frontier technologists launched a bold search for stresstolerance genes, with the aim of genetically adapting existing plants to more extreme conditions. ETC called attention to the intensification of this search, warning that big corporations are quickly appropriating the field through gene patents that make overly broad claims (covering many species under the same patent file) and in so doing take room to operate away from others. The report, 'Patenting the 'Climate Genes' and Capturing the Climate Agenda', ${ }^{18}$ sounds the alarm on the fact that a few big companies are "stockpiling hundreds of monopoly patents" on genes that look promising for stress tolerance. Three companies (BASF, Syngenta and Monsanto) are responsible for two-thirds of the patent filings in this area. According to the companies, gene-altered plants will be crucial to solving world hunger and will never be developed without patent protection. By forming partnerships with public 
agricultural research institutes ${ }^{19}$ and the Bill and Melinda Gates Foundation, they want to make these solutions available for the poor. Drought-tolerant maize for subSaharan Africa is the spearhead. According to the ETC group, however, this is a PR offensive in which the corporations themselves are the biggest winners. ETC instead advocates a farmer-based approach that starts from local plant varieties, farmer-tofarmer alliances and the investigation of under-utilized species as a resource for useful traits. ETC here sides with the IAASTD report mentioned earlier, which also argued for the strengthening of farmer's strategies.

The ETC group is proud of its long and tenacious history of watchfulness in the name of human rights, and this is indeed one of its main heroic characteristics. Its critical role is a demanding one. It renders the group unable to fully follow an agenda of its own; instead, they have to follow frontier activists wherever they choose to go. The permanent danger that confronts inspectors is exhaustion through lack of positive results.

The heroism of ETC's critical watchfulness is easily overlooked, like ELSI's, and like the heroism of criticism and scepticism in general. Stephen Jay Gould has celebrated scepticism, ${ }^{20}$ writing that the need for it arises from the fact that we are not rational creatures but "thinking reeds", that is to say powerful but also vulnerable creatures. We need to attend to that vulnerability. Scepticism and the debunking of false claims, says Gould, often has the bad reputation reserved for activities like garbage disposal, that are necessary but very unglamorous. But scepticism should not only be regarded as a negative removal. Proper debunking has more to offer, since it is done in the name of moral decency - "the most powerful joint instrument for good that our planet has ever known."

\section{Subversive farmers: Pirates of GM seeds}

Development of GM seeds is increasingly in the hands of a few very large multinational companies, with Monsanto as the leading one. Increasingly, criticism of GM technology from watchdogs such as ETC does not primarily focus on transgenic technology as such, but on the conflicting interests of big powerful multinational companies on the one hand and small powerless farmers on the other.

Biotechnological R\&D is expensive and is therefore mainly in the hands of big and powerful corporations. ${ }^{21}$ Thus, at first sight, opposition against the power of multinationals aligns well with opposition to biotechnology, while a pro-farmer strategy coincides with an anti-GM strategy. But the choices of farmers in developing countries, such as India, Brazil and China, have not followed this straightforward dualism, and change the familiar pro-con GM picture.

Developments in Gujarat in India have been reported most widely. In 2001, the state of Gujarat was struck by a bad attack of bollworms, which infect cotton plants. But some fields prospered, and these fields turned out to be planted with a seed variety that (illegally) contained a gene on which Monsanto had a patent, and for which it had been trying for years to obtain selling permission in India. The seeds were banned, but the bollworm-protecting gene did not disappear from Gujarat. Farmers continued to

Genomics, Society and Policy, Vol.5, No.3 (2009) ISSN: 1746-5354

(C) ESRC Genomics Network. 
breed plants from the seeds they saved, discovering that the second generation was also resistant to bollworms. Local seed companies commercialized the descendant seeds, and a thriving industry of Bt cotton seeds came into existence. It has been estimated that in 2005, 80 per cent of the cotton in Gujarat was grown from illicit Bt seeds. $^{22}$

In an article on the situation in Gujarat, in which he calls the Indian breeders and farmers "The Napster pirates of transgenic biotech", Andrew Leonard ${ }^{23}$ writes that if this "anarcho-capitalism" is an indication of what is yet to follow, then we are bound to see an "incredible mess": corporations will be unable to control the use of their seeds, green activists will be unable to prevent their use, while governments will be unable to implement safety measures. Yet perhaps, Leonard continues, we need not be dismayed by this mess, since:

One encouraging lesson is that while the Monsantos of the world are extraordinarily powerful, they are not all powerful. Another could be the observation that transgenic biotech can indeed make a positive difference in the lives of farmers, especially when they are given the freedom to experiment and adapt. Yet another is that farmers are not automatically helpless pawns in the face of corporate capital - they can co-opt new technologies and create new agricultural practices. ${ }^{24}$

Thus, developments in India (and China, and Brazil) have been undermining the idea that GM technology is simply bad for small farmers, and so they also undermine the traditional lines of division in GM debates. A situation in which farmers bypass patents and safety regulations because they expect benefits from GM seeds is far more complex and locally variable. In this new situation, the question whether, and under which conditions, farmers can profit from GM technology, is receiving new answers. For example, Ronald Herring points out that in China both the public and the Monsanto versions of $\mathrm{Bt}$ cotton have been adopted rapidly by small farmers. ${ }^{25} \mathrm{He}$ stresses that this does not point to irrationality on the part of farmers: they have done it for higher yields, less pesticide application, and higher profits.

Poor farmers thus became heroes of biopiracy, challenging the power of the big multinational companies. The dangers for them include legal countermoves from the powerful companies.

The "incredible mess" caused by the Gujarat farmers is one of the factors taking GM debates into an interesting new phase. The Gujarat undermining of GM patents can be seen as part of a larger shift, in which the main issue of GM is no longer the technology itself, but matters of power and property. Debates on GM technology are shifting accordingly: intellectual property has replaced risk as the main issue, as the ETC arguments also illustrate. ETC and Gujarat farmers alike are engaged in a fight against the power of big companies, not against GM. The shift is also apparent in the rapid increase in initiatives and the avalanche of literature on open source and other alternatives to the traditional patent system, which amount to a fundamental 
rethinking of intellectual property rights. Intellectual property and power relations are becoming the main issues of GM debates, which thereby cease to be GM debates.

Can these first three heroes be understood by seeing them as a family? Lakoff argues that the overarching differences between American conservatives and liberals can be understood in terms of different views of the family. ${ }^{26}$ Family metaphors, he says, unite views that might otherwise seem fragmented. Conservative political thought can be characterized as a "strict father" morality, while the family that underlies liberal thought is a family of "nurturant parents". The background of the strict father view is that the world is fundamentally dangerous. In a traditional family, the father has the central role of protection and authority. He sets strict rules which he enforces through punishment. It yields a moral and political system which is characterized by authority, obedience, discipline, self-reliance and competition, hierarchy and a strict separation of good and evil. The role of the mother is one of care and support.

Lakoff's description sometimes looks like a caricature of strictness. We are not concerned here with the question to what extent this metaphorical system really describes and explains US politics. But we note that, at first sight, frontier heroes can be looked at as traditional fathers, and ELSI can be seen as a traditional mother. Does high tech innovation come with the roles of traditional families, with the Gujarat farmers as the children?

This interpretation immediately suggests that the traditional family is in trouble. Mother ELSI is assisted in her role by independent and critical inspectors who are not part of the family and who severely criticize the power of the father, while the children in Gujarat, instead of being obedient and self-disciplined, have become rebellious. If the big hero of technological innovation is a powerful and authoritative father, his power seems to be seriously under attack. Yet this suggestion of crisis is at least partly an artifact of our description: obedient children are all around, but they catch the eye less easily when you are looking for heroes who are setting new trends.

We will return to the explanatory force of family metaphors at the end of the paper. But for the next three heroes, not associated with technology, the question becomes: would the "nurturant parent" family be a helpful concept to understand them?

In contrast to the first three heroes, the next three are not associated with GM, or high tech in general. Our relationships with nature seem to be their main concern. What they worry about might be summarized as the "misguided faith in the hegemony and infallibility of the human power to control the natural world", to use Eric Katz's words. ${ }^{27}$ Backgrounds for this concern can be found in ecological theory; already during the 1960s ecologists such as C.S. Holling warned that the command-andcontrol approach had become ever more expensive, irrational and finally counterproductive. ${ }^{28}$ These ecologists do not argue for a complete dismissal of control but for "controlled decontrolling of ecological controls", as it could be called with a wink to the civilization theory of Norbert Elias. ${ }^{29}$ Cases in point are the 'prescribed'

Genomics, Society and Policy, Vol.5, No.3 (2009) ISSN: 1746-5354

(C) ESRC Genomics Network. 
use of fire ('fighting fire with fire') and the reintroduction of large predators. Another example is flood control in the Netherlands.

\section{Polder heroes of saline agriculture}

Large parts of the Netherlands lie below sea level or below the high-water level of the major rivers. As early as the mid-14th century, a nearly completely connected system of dykes arose to protect the land from floods. But in recent years, with the land subsiding and water levels rising, the traditional approach to flood control - dyke reinforcements - has become inadequate. In 1996, the Dutch government therefore decided to modify the traditional water policy of dyke reinforcements. Instead of restricting rivers in straightjackets of dykes, the new policy of flood risk reduction aims to create more room for rivers and to restore the self-regulating capacities of water systems. The 'war on water' is being replaced by a 'dialogue with water', in which water engineers have replaced their authoritarian and technocratic attitude by a more modest and respectful attitude.

One element of this shift has to do with an increasing agricultural problem: how to deal with the salinization of Dutch soils? Salt has historically been seen as a major problem for agriculture. One of the traditional goals and priorities of Dutch water policy was to supply agriculture with all the fresh water it needed. According to the new view, however, the Netherlands would do well to see the salinization of soils not as a problem but as a challenge for innovation: the development of "saline agriculture". Our hero here is the Innovation Network (Innovatienetwerk), a public organization established in 2000 and funded by the Dutch government. ${ }^{30}$ Its study Saline Perspectives addresses the problem of the increasingly saline Dutch soils and argues that the possibilities to stop salinization are diminishing. We need a new perspective on agriculture, the study argues, a perspective that puts water instead of land in a central place. Brackish and salt water should have a place alongside fresh water in this new agricultural paradigm. ${ }^{31}$

The report gives an overview of the potential use of brackish and salt water for agricultural purposes. It emphasizes that problems can rapidly be turned into opportunities, since many potential solutions are near at hand. Brackish water, for example, is eminently suitable for growing traditional salt-tolerant crops such as barley as well as new ones (new, that is, from a commercial perspective) such as protein-rich Lemna (duckweed). Salt water also offers opportunities for commercial production of many traditional food plants, such as Salicornia (glasswort). In short, salt-tolerant crops should be rediscovered. Furthermore, estuarine areas are highly valuable from environmental and recreational perspectives. The report stresses that the change of perspective amounts to a "system innovation" 32 and should be based on a new consensus. This in turn requires the effort and cooperation of many parties: entrepreneurs, researchers, policymakers and other societal groups. Our heroes represent the Dutch polder system, which looks for change through consensus formation. 
This transition attempt has not met with immediate success. In 2007, the Innovation Network took a new look at the saline Dutch soils. ${ }^{33}$ The urgency and extent of the problem had only grown, but despite all this promise, they noticed that saline agriculture showed no signs of expanding; it seemed to be caught in a vicious circle of small demand and small production. ${ }^{34}$ Governmental as well as agricultural and research institutions remained firmly focused on a fresh-water-dependent agriculture. The reports deplored this lack of activity, as substantial areas were rapidly becoming less useful for traditional agriculture and landscape development. The need for vision, creativity, courage, and a big change of attitude was again stressed. ${ }^{35}$ The authors repeated the availability of traditional, near-at-hand solutions and the interesting combinations with tourism and nature development. They also introduced some new ideas, such as 'salt villages' and 'salty estates'.

Meanwhile, signs of change are beginning to accumulate in areas other than agriculture; for example, floating houses meet with ever more interest. Maybe the Innovation Network needs a little more patience. For this paper, the main point is that in this approach, innovation is disassociated from new technology. The Network primarily focuses on innovative and more flexible perspectives. Development and breeding of new crops are mentioned, but the emphasis is overwhelmingly on the excellent opportunities offered by traditional salt-tolerant plants. This low tech profile may well be the result of the pragmatic consideration that GM solutions might be helpful but are too controversial.

\section{Urban Gardeners: lawns for agriculture}

The next heroes of innovation, also with a low tech profile, are urban gardeners. "You may recall International Sunflower Guerrilla Day on 1 May", Richard Reynolds wrote triumphantly on his Guerrilla Gardening blog on 30 August, $2008{ }^{36}$ A photo showed some of the resulting sunflowers, with the UK Houses of Parliament in the background: the "Incredible guerrilla garden of sunflowers of Parliament". Guerrilla gardening originated in the 1970s in New York and is a political activity. Reynolds' blog, started in 2004, records his illicit cultivation in London and quickly became a meeting point for many people in "the war against the neglect of public space". The movement inspires many people: in his book On Guerrilla Gardening Reynolds describes activities in almost 90 cities in many countries. ${ }^{37}$

Political gardening also takes forms with direct agricultural relevance. For example, in Edible Estates: Attack on the Front Lawn, architect and artist Fritz Haeg describes his "Edible Estates" project, in which he encouraged people in various US cities to break with the laws of decency and turn their front lawns into vegetable gardens. ${ }^{38}$ Those pioneers were more or less isolated "street performers", but Haeg's dreams extended far beyond such moderate beginnings: "What if all the front lawns on the entire street were turned over to urban farming teams?"39 The edible estates initiative clearly fits in with urban agriculture, the practice of growing food in and near cities. This is not at all something new, as Haeg was happy to acknowledge. Celebrated forerunners are the so called Victory Gardens in World War II, household gardens which towards the end of the war delivered a considerable percentage of vegetable food production.

Genomics, Society and Policy, Vol.5, No.3 (2009) ISSN: 1746-5354

(C) ESRC Genomics Network. 
20 March, 2009 was a landmark day in the development of urban gardening: First Lady Michelle Obama started the White House kitchen garden. It quickly became very productive, according to the White House blog: "in the past few months it has already yielded over 1,000 pounds of produce. We use this fresh produce in meals for the First Family, in dinners for foreign leaders and we donate a good portion of it to Miriam's Kitchen, a nearby soup kitchen."

The heroes of urban gardening are playful, artistic, educational and political. They are committed to empowerment through reclaiming public space and getting in touch with food production again. One of the prominent authors of the movement is Michael Pollan. "Lawns", he writes, "are symptoms of, and a metaphor for, our skewed relationship to the land. They teach us that, with the help of petrochemicals and technology, we can bend nature to our will. Lawns stoke us with hubris with regard to the land". The alternative, the garden, teaches us "the necessary if rather unAmerican lesson that nature and culture can be compromised." Pollan feels at home in the garden, and is unhappy that the wilderness ethic dominates environmental ethics, as it tends to write off the more than 90 per cent of the landscape that is used by humans, he told an interviewer. ${ }^{42}$ In the same interview, speculating about the reasons why old and simple ideas about gardening are now appealing to so many people, he says that people have outsourced too many aspects of their lives. Gardening is a way to fight feelings of powerlessness, as it teaches that you can actually feed yourself: "The beginning of knowing how to change is learning how to provide for yourself a little bit more."

"The best ideas are usually the simplest ones", writes Eric Schlosser on the back cover of Haeg's book; "Instead of mowing your lawn, you should eat it." The heroes of urban gardening may be marginal in many respects, but by not writing off the city from environmental and agricultural points of view they are inspiring. Not accidentally, the garden is a familiar metaphor for the reconciliation of nature and culture. In public as well as private city corners, flowers can grow, healthy food can be produced and daily life can gain in quality. The Victory Gardens of World War II showed that many small gardens can add up to a big difference. The do-it-yourself and playful atmosphere is an important aspect of the energy and inspiration of urban agriculture. Though this may not look very heroic, pioneer "street performers" certainly need some courage, for example in breaking unspoken laws of lawn decency.

\section{Lone treasurers: harmonious living}

In contrast to the urban gardeners, our last hero shuns the city and ends up in isolation.

In 2008, a documentary on Dutch television called Eternal Mash ${ }^{43}$ focused on an initiative called the Oerakker, and the people associated with it. On a field in a rural part of the Netherlands, Ruurd Walrecht had made great efforts to cultivate and preserve traditional and forgotten varieties of vegetables. He collected traditional

Genomics, Society and Policy, Vol.5, No.3 (2009) ISSN: 1746-5354

(C) ESRC Genomics Network. 
plants and seeds from all over the country, loving and cherishing their diversity and deploring the impoverishment of present day varieties and tastes. The documentary could not show the daily work on the Oerakker, however, as it had ended.

Demoralized through years of problems, opposition and lack of financial support, Walrecht abruptly ceased all his farming activities in 2006 and left the country. In the documentary, three of his former collaborators look back on his work and mourn his departure. Two of them live self-supporting lives in close contact with nature, while the third now devotes his life to religion. They are not in contact with new technological or new social developments; on the contrary, the idea inevitably arises that the Oerakker has been the work of rather unusual and marginal people, devoted to living in harmony with nature.

But the documentary continued by showing that the seeds Walrecht left behind were being collected, frozen and stored by scientists at Wageningen University. The scientists explain that they consider it very important to preserve the genetic diversity represented by those seeds. The University also makes such material available to researchers from outside the university, and one of the Wageningen scientists, Professor Edith Lammerts van Bueren, comments that it is a sour thought that biotechnology firms might end up using the Oerakker seeds for GM purposes. The contrast with the spirit of the Oerakker is indeed stark.

The Oerakker case suggests that an active interest in the cultivation of traditional plant varieties - as opposed to the preservation of their genes in genetic storage banks - is neglected by science. The Oerakker heroes, caring strongly about forgotten varieties of vegetables, are marginal people, who did not succeed in convincing subsidizers of the importance of their work. The scientific innovators focus on genes: they are important for scientific and biotechnological goals. The suggestion in this documentary is that approaches that build on local and traditional (low tech) knowledge are out of tune with the dominant innovation climate, in which frontier technology, controversial though it may be at the same time, is central, and in which the settings are global. Yet one cannot help but wonder what would have happened if the documentary maker had come a little earlier: could she, and the new attention and interest raised by the programme, have saved the Oerakker?

It is perhaps misleading to present the Oerakker as a case of innovation. Conservation and rehabilitation are more conspicuous here than innovation. But the fate of the Oerakker may also shed some light on the faltering attempts of the Innovation Network to accomplish an innovative approach to saline soils with the help of traditional plant varieties. Could this approach be too far removed from the technological frontier and (therefore) from still-dominant views of innovation?

\section{Discussion}

Innovation is strongly identified with activities on the frontier of science and technology. This implies that our first hero attracts attention more easily than the others. But though this association is not wrong, it is one-sided, because such innovation takes its starting points in the frontiers of science and the excitements of

Genomics, Society and Policy, Vol.5, No.3 (2009) ISSN: 1746-5354

(C) ESRC Genomics Network. 
discovery, rather than in the complexities of daily life. The second and the third hero are also involved with frontier technology, but in critical ways. The issues that turned out to underlie their activities, however, no longer primarily have to do with the technology itself, but with inequalities of power and property. The same can be said of the (pro-) technology approach of the subversive farmers in India; they are interested in the technology because it increases productivity and income. The GM debate is in the process of being replaced by a different debate, about systems of intellectual property and their consequences for the poor and powerless.

The last three heroes are low-tech innovators. Innovation has a different form here, in which changes of perspective are central. To adapt to saline soils, to eat your lawn, to look at varieties of vegetables as priceless treasures - these are all invitations to adopt new ways of seeing and thinking. Though no high tech is involved, it does not follow that (anti-) technology is the main issue. Here, too, there are other things at stake. For at least two of these three heroes, the saline adapters and the urban gardeners, the low tech approach looks more like a matter of pragmatism rather than of principle. The aims are pro-something-else rather than anti-technology: the polder heroes are looking for the most practical adaptations to saline soils, the urban gardeners look for ways in which people in their daily lives can actively relate to food and the land in sustainable ways.

In short, framing the differences between the heroes in terms of pro- and anti technology attitudes is at least partly beside the point. Framing them in terms of their goals can help to encourage a more pragmatic and less dualistic approach towards technology, in particular GM technology: neither is it a silver bullet, nor an inherent recipe for disaster.

Returning to Lakoff's family metaphors: can the low tech innovation heroes be seen as a liberal family with nurturant parents? According to Lakoff, the nurturant parent family, the moral model for liberal Americans, is characterized by care, egalitarian relations and open, two-way communication. There is something that seems to fit here: saline adaptationists, with their hope of achieving consensus on a new perspective, look like the prototype of deliberative and anti-hierarchical decision makers. They may be seen as the egalitarian parents of the low tech family, with the urban gardeners as their assertive, politically leftist and artistic children. The lonely nature dwellers are harder to fit into this family; they may have dropped out of traditional families; or rahter they are hard to fit in with any family at all. To summarise, the family metaphor offered some suggestive leads, but in the end it is too limited and too rigidly dichotomic to be really illuminating for our heterogeneous set of innovative heroes. The heroes are too individualistic to fit the scheme. A dualistic pattern with regard to technology simply does not fit. Such dualism may satisfy our need for order and for quick moral distinctions, but it does not do justice to the heterogeneous diversity of innovative directions.

We do not intend our inventory to be complete, and of course it is not static; new and different heroes keep turning up. ${ }^{44}$ A grand dichotomy, for example the one between

Genomics, Society and Policy, Vol.5, No.3 (2009) ISSN: 1746-5354

(C) ESRC Genomics Network. 
an industrial and a multifunctional agriculture that we mentioned in the introduction, will not do to capture all their quests. Such overarching dichotomies always tempt us to associate another dichotomy with it, between an old model or worldview, which is bad, and a new one, which is good. Not all roads to the future are equally attractive, but that does not imply that there is one best way. Pluralism, unheroic though it may sound, is an important value.

\section{Acknowledgments}

For Cor van der Weele, this paper is an outcome of the project 'Towards a lingua democratica for public debate on genomics'. The project was subsidized by the Netherlands Organization for Scientific Research (NWO) and carried out at the University of Humanistics in Utrecht. She thanks the research team and in particular the project leaders, Professor Peter Derkx and Professor Harry Kunneman, for fruitful cooperation. We also thank two anonymous reviewers and Claire Packman for helpful suggestions.

\footnotetext{
${ }^{1}$ Wageningen University and Research Centre, the Netherlands. cor.vanderweele@wur.nl

${ }^{2}$ International Assessment of Agricultural Knowledge, Science and Technology for Development. 2008. Agriculture at a crossroads. Global Summary for decision maker..Agriculture at a Crossroads. Global Report. 2009. Washington, D.C., IAASTD. Available at: http:/www.agassessment.org/

${ }^{3}$ E.Stokstad. Dualling Visions for a Hungry World. Science 2008; 319: 474-476.

${ }^{4}$ One reviewer suggested that the choice of the term might, contrary to our intentions, contribute to the dominance of the first hero, and suggested we use "pioneers" as a more neutral overarching term. But this term equally applies best to the first group of innovators. We hope that our pluralistic intentions are conspicuous enough to outweigh status-quo-affirming associations.

${ }^{5}$ Had we set up the paper later, we might for example have included heroes who contest the assumption that economic growth is necessary. The arguments for high tech innovation are closely interwoven with the dogma of growth, and are now increasingly attacked. See T. Jackson. 2009 Prosperity Without Growth. Economics for a Finite Planet. London, Earthscan.

${ }^{6}$ See e.g. L.Soete. 2008. International Research Partnerships on the Move. In Knowledge on the Move. Emerging Agendas for Development-oriented Research. H. Molenaar, L. Box, R. Engelhard, eds. Leiden, International Development Publications, 33-48

${ }^{7}$ G. Lakoff. 1996. Moral Politics. How Liberals and Conservatives Think. Chicago, University of Chicago Press.

${ }^{8}$ F.J. Turner. 1893. The Frontier in American History. Chapter 1. Available at: http://xroads.virginia.edu/ HYPER/TURNER/

${ }^{9}$ See e.g. R. Slotkin. 1992. Gunfighter Nation. The Myth of the Frontier in Twentieth-Century America. New York, Atheneum. One example: In July 1960, in his speech to accept the Democratic Party's nomination as candidate for president, John F. Kennedy told his audience that America should confront a different kind of wilderness journey in a new frontier endeavour: "We stand at the edge of a new
} 
frontier - the frontier of unfulfilled hopes and dreams. Beyond that frontier are uncharted areas of science and space, unsolved problems of peace and war, unconquered problems of ignorance and prejudice, unanswered questions of poverty and surplus."

${ }^{10}$ A.D. Dreger. 2000. Metaphors of Morality in the Human Genome project. In Controlling Our Destinies: Historical, Philosophical, Ethical, and Theological Perspectives on the Human Genome Project. P. Sloan, ed. Notre Dame, IN, U. Notre Dame Press: 155-184.

${ }^{11}$ J.C. Venter. A DNA-driven world. The $32^{\text {nd }}$ Richard Dimbleby Lecture. BBC One. 2007. www.bbc.co.uk/pressoffice/pressreleases/stories/2007/12 december/05/dimbleby.shtml ${ }^{12}$ Venter is controversial as a scientific hero because he is also a commercial entrepreneur. He is attacked by other scientific frontier heroes, such as John Sulston, who opposes commercial exploitation, and believes that science should be governed by a different ethos; the genome should be seen as the common heritage of mankind. Sulston is therefore a more complex hero, who combines the spirit of discovery of the frontier with the protection of vulnerable values, characteristic for the next hero.

${ }^{13}$ Venter op. cit. note 11: "The pedantic argument concerning future inventions is how can we count on new technologies that don't yet exist? Some can look at the past and see no change for the future, while others will extrapolate forward in a linear manner. However, there are some fields where predicting and counting on exponential change has become reasonable and reliable. For example, Gordon Moore, a founder of the computer chip giant Intel, predicted that the density of transistors on integrated circuits would double every two years, a prediction that became referred to as Moore's Law. Similar exponential growth is seen in genomics - a term that did not even exist prior to the 80's. Our ability to read the genetic code is changing even faster than changes predicted by Moore's Law."

${ }^{14}$ J.M. Keynes. 1973 (1936). The General Theory of Employment, Interest and Money, London, Macmillan.

${ }^{15}$ J.R. Jeffrey. 1998 (revised edition). Frontier Women: Civilizing the West? New York, Hill and Wang.

${ }^{16}$ C. van der Weele. Moral Agendas for Genomics. How to Find the Blind Spots?. Configurations 2008; 16(1): 117-136.

${ }^{17}$ ETC: to be pronounced as etcetera. RAFI: Rural Advancement Foundation International

${ }^{18}$ ETC. 2008. Patenting the 'Climate Genes' and Capturing the Climate Agenda. http://www.etcgroup.org/en/node/687

${ }^{19}$ CIMMYT (International Maize and Wheat Improvement Center), one of the 15 public research institutes that operate under the umbrella of CGIAR, the Consultative Group on International Agricultural Research.

${ }^{20}$ In the foreword to M. Shermer. 2002. Why We Believe Weird Things. New York, Freeman.

${ }^{21}$ It is so expensive because it requires expert knowledge on patents and safety regulations as well as biology. Ironically, critical NGO's such as Greenpeace and ETC may unwittingly have contributed to the concentration of multinational power, as their opposition has encouraged strict regulations, which render the development of transgenic seeds so expensive that only the biggest companies can afford the R\&D.

${ }^{22}$ Our descriptions are snapshots in time. Since the first draft for this paper (August 2008), all the heroic endeavours discussed here have undergone further developments, of which we have mentioned only some. None of the heroes has lost its relevance. As to Bt cotton: at the time we finalized this paper for publication (June 2010), it was still a highly contested issue in India.

${ }^{23}$ A. Leonard. 2007. The Napster Pirates of Transgenic Biotech.

http://www.salon.com/technology/how_the_world_works/2007/02/08/gujarat

24 Ibid

${ }^{25}$ R.J. Herring. Stealth Seeds: Bioproperty, Biosafety, Biopolitics. J. Developmental Studies 2007; 43/1: 130-157. See also R.J. Herring. The Genomics Revolution and Development Studies: Science, Poverty and Politics. J. Development Studies 2007; 43 (1): 1-30

${ }^{26}$ Lakoff, op.cit. note 7, pp 65-69.

${ }^{27}$ E. Katz. 2003. The Big Lie: Human Restoration of Nature. In Environmental Ethics. An Anthology.

A. Light and H. Rolston, eds. Cambridge, Blackwell Publishers: 396.

${ }^{28}$ C.S. Holling G. K. Meffe. Command and Control and the Pathology of Natural Resource

Management. Conservation Biology 1996; 10(2): 328-337. Over the past decades, the ideal of total

Genomics, Society and Policy, Vol.5, No.3 (2009) ISSN: 1746-5354

(C) ESRC Genomics Network. 
control over nature has crumbled as a result of the shift within ecology from equilibrium theory to nonequilibrium theory. The dynamic and non-linear nature of ecosystem development was already recognized by Henry Allan Gleason in the early 1900s; it became the focus of renewed attention in the 1970s through the work of Robert May and Crawford Stanley ('Buz') Holling, the father of the socalled 'resilience approach'.

${ }^{29}$ Elias differentiates between roughly two phases in the Western civilizing process. In the period from 1200 until 1750 people learned to repress spontaneous reactions. In the following period they were expected no longer to simply repress their feelings and emotions but to express them in a 'controlled' way. This form of self-restraint Elias has called 'controlled decontrolling of emotional controls'. Likewise, we can characterize the new types of flood, fire and predation management as 'controlled decontrolling of ecological controls' (I. Klaver, J. Keulartz et al. 2002. Born To Be Wild. A Pluralistic Ethics Concerning Introduced Large Herbivores in the Netherlands. Environmental Ethics 24(1): 3-23.)

${ }^{30}$ Its task is to promote boundary breaking innovations aimed at sustainable development of agriculture, the food chain and the Dutch landscape.

${ }^{31}$ J.L. Fiselier, ed. 2003. Zilte Perspectieven. Innovatienetwerk Groene Ruimte en Agrocluster, Den Haag

${ }^{32}$ Ibid; p. 37.

${ }^{33}$ H. Guldemond, W. Tolkamp, L. Van der Weijden. 2007. Zilt verweven. Kansen voor een gezamenlijke ontwikkeling van zoute landbouw en natuur. Innovatienetwerk, Den Haag. J.G. de Kempenaer, W.A. Brandenburg, L.W.J. van Hoof. 2007. Het zout en de pap Een verkenning bij marktexperts naar langeretermijn-mogelijkheden voor zilte landbouw. Innovatienetwerk, Den Haag. Innovatienetwerk. 2007. Van zoute schade naar zilte oogst. Voortgangsrapportage. Den Haag.

${ }^{34}$ In September 2008, the website of the Innovation Network mentioned one example of commercial saline agriculture in the Netherlands: the combined efforts of Happy Shrimp Farm and the Salicornia firm Green and Blue on the Maasvlakte near Rotterdam. In its comment on the initiative, the Innovatienetwerk repeats its complaint that saline agriculture is not yet getting the attention it deserves. http://www.innovatienetwerk.org/nl/concepten/view/116/Zilteteeltenondereendak.html

${ }^{35}$ Innovatienetwerk. 2007. Van zoute schade naar zilte oogst. Voortgangsrapportage. Den Haag.

${ }^{36}$ R. Reynolds: http://www.guerrillagardening.org/

${ }^{37}$ R. Reynolds. 2008. On guerilla gardening. A handbook for gardening without boundaries. London, Bloomsbury.

${ }^{38}$ F. Haeg. 2008. Edible Estates. Attack on the front lawn. New York, Metropolis Books.

${ }^{39}$ Ibid; p. 27.

${ }^{40} \mathrm{http}$ ://www.whitehouse.gov/blog/2010/01/05/iron-chefs-and-healthy-eating

${ }^{41}$ M. Pollan. 2008. Why Mow? The case against lawns. In Edible Estates. Attack on the front lawn. F. Haeg, ed. New York, Metropolis Books: 28-35.

${ }^{42}$ M. Pollan. 2008. What's wrong with environmentalism. An interview by Kate Cheney Davidson http://www.alternet.org/module/printversion/90785

${ }^{43}$ Catherine van Campen: Eeuwige Moes. Documentary. http://www.hollanddoc.nl/kijkluister/documentaire/e/eeuwige-moes-ode-aan-het-gewas.html

${ }^{44}$ See note 4. For example, Bill Gates is a high tech hero who, in response to criticism, is hybridizing. In his Speech at the 2009 World Food prize Symposium, he defended the value of new technological development that creates new seeds, but small farmers too were at the centre of attention: "developing these more productive seeds is just one element of an overall strategy. (...) We try to see our investments through the eyes of small farmers. (...) We try to be responsive to the needs of the farmers themselves, and in particular that includes looking at the expertise of women farmers who do most of the farming in Africa." http://www.gatesfoundation.org/speeches-commentary/Pages/bill-gates-2009world-food-prize-speech.aspx 